\title{
A Hoard of Military Awards, Jewellery and Coins from Colchester - Corrigendum
}

\author{
By NINA CRUMMY
}

With contributions by MARTIN HENIG and COURTNEY WARD

doi: 10.1017/S0068113X16000027, Published by Cambridge University Press, 11 February 2016.

There was an error in the article by N. Crummy, M. Henig and C. Ward. Under the heading 'Coins' the opening sentence should read 'Twenty-eight coins were in the purse...'.

\section{BIBLIOGRAPHY}

Crummy, N., Henig, M. and Ward, C. A Hoard of Military Awards, Jewellery and Coins from Colchester. Britannia, available on CJO2016. doi:10.1017/S0068113X16000027. 